\title{
Design and Simulation of Positive Net Energy Building in Tropical Climate
}

\author{
Anirban Chakraborty
}

\section{Introduction:}

The design and simulation of smart home control in tropical climate deals with the thermal simulation of a residential building which is located in the Indian capital city of New Delhi [N $28^{0} 34^{\prime}$ ] [E $77^{\circ} 11^{\prime}$ ]. It gives an idea of the amount of energy consumed and wasted throughout the year based on 3 input considerations i.e., the building materials, the weather data and the zone loads. The building uses electricity for to run its space heating system, lighting and appliances and to heat domestic hot water. The thermal simulations have been done using the software Energy Plus and Open Studio plug-in which will give the amount of generates, consumed and purchased energy with time step, monthly and yearly values. In order to save some amount of the electrical energy supplied by the utility grid to the house mains, we are installing solar photovoltaic panels on the roof of the house. It also takes in to account the day lighting results according to its geographical conditions. The next phase of the project deals with efficient lighting inside the house in order to save the energy used in interior lighting. The effects of lighting inside the house will be shown using RELUX. The last part of the report deals with solar panel design.

The results obtained from this project give us a detailed data of the heating, cooling and lighting loads across the year and how they are varying through the months. It also gives the day lighting results i.e., the lux levels in each room and the glare index levels. The panel design gives the entire detail from installation to the payback period.

\section{Background and Motivation:}

The smart home control project is an adaptation to the work done on a residential building in a Serbian environment. Due to the increasing energy demand at all levels in the consumer sector, there needs to be an alternate source of generation to meet this demand. Thereby we show the efficient generation of power using solar photovoltaic cell on a residential level. Residence is the most elementary level where we can start bridging the huge gap of $25 \mathrm{GW}$.

As far as the social theme is concerned, this project is entirely directed towards the conservation of electrical energy on a domestic level. When started at this scale and then propagated to higher scales, it will save the environment for generations to come. The inspiration for this project comes from need for the increasing amount of energy consumption in all levels across the globe which threatens mankind about the limited stores of energy which nature has for us. With the rise in population and more urbanization, commercial and engineering activities are also expected to rise, thus demanding larger share of energy in an already strained energy supply scenario. Conventional sources of energy have a limited store and cannot last for infinite time with the increasing demands. Renewable sources are of great help and solar energy is the most gigantic form of renewable energy available to us.

Thus the background and motivation of this project is mainly energy efficiency which is of primary concern today because of the fast finishing resources of the world which are supplying to the increasing demands of the consumers.

\section{Objectives}

- To obtain thermal and day lighting simulation for a residential building in tropical climate using Energy Plus.

- To provide and visualize energy efficient lighting solutions using Relux.

- Design solar panel for Negative Net Energy Building [NNEB], Positive Net Energy Building [PNEB] and Zero Net Energy Building [ZNEB].

The main softwares which have been used for this project are:

- AUTOCAD 2012 


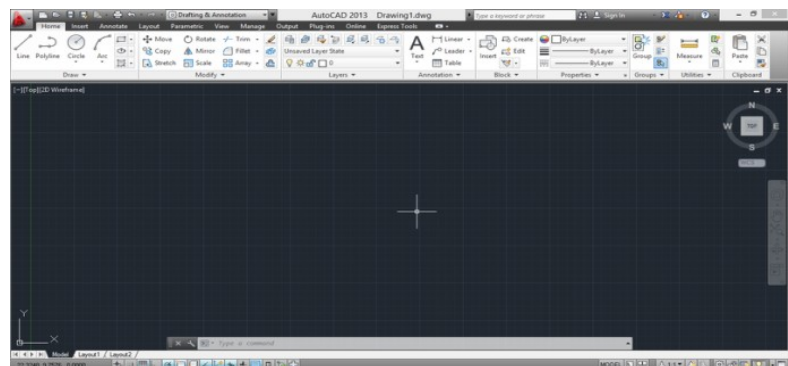

- GOOGLE SKETCUP PRO 8 [WITH LEGACY OPEN STUDIO PLUG-IN]

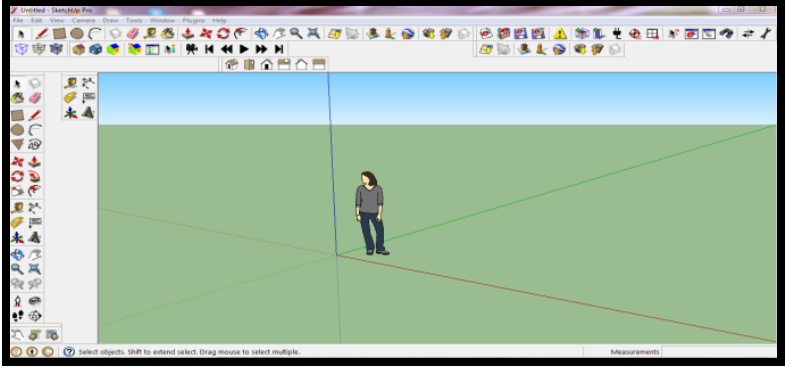

- ENERGY PLUS

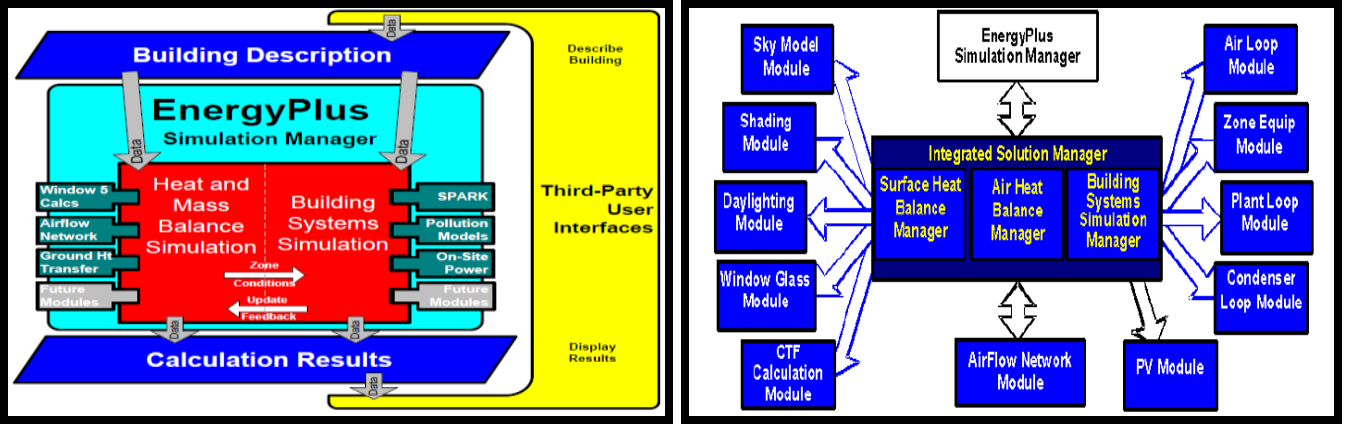

- RELUX

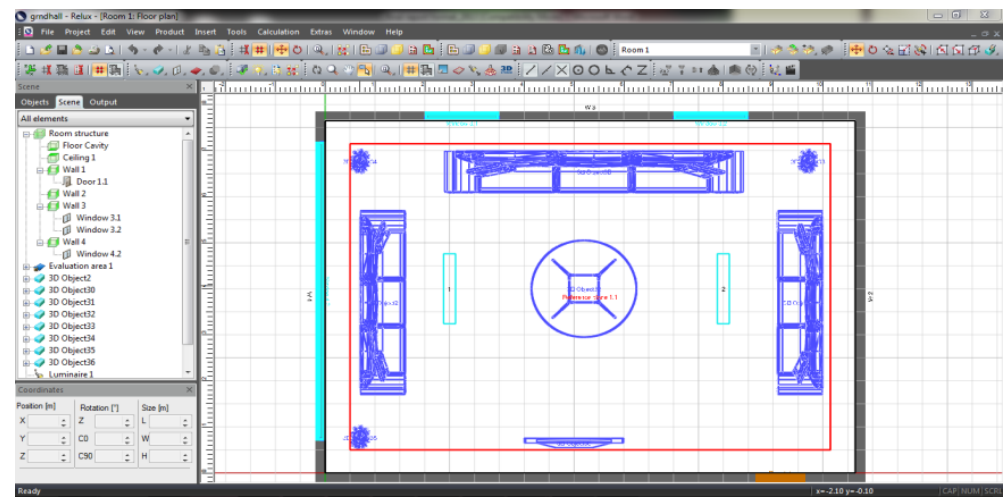

HVAC [HEATING, VENTILATION \& AIR CONDITIONING]:

HVAC stands for Heating, Ventilation and Air Conditioning. It is the technology of indoor and automotive environmental comfort. HVAC system design is a sub discipline of mechanical engineering, based on the principles of thermodynamics, fluid mechanics, and heat transfer. Refrigeration is sometimes added to the field's abbreviation as HVAC\&R or HVACR, or ventilating is dropped as in HACR (such as the designation of HACR-rated circuit breakers). many others.

The three central functions of heating, ventilating, and air-conditioning are interrelated, especially with the need to provide thermal comfort and acceptable indoor air quality within reasonable installation, operation, and maintenance costs. HVAC systems can provide ventilation, reduce air infiltration, and maintain pressure relationships between spaces. The means of air delivery and removal from spaces is known as room air distribution.

HVAC simulation in this project is limited to two components mainly:

Thermostats

Air Conditioning 
Solar panel:

A solar panel (also solar module, photovoltaic module or photovoltaic panel) is a packaged, connected assembly of photovoltaic cells. The solar panel can be used as a component of a larger photovoltaic system to generate and supply electricity in commercial and residential applications. A photovoltaic system typically includes an array of solar panels, an inverter, and sometimes a battery and or solar tracker and interconnection wiring. Solar panels use light energy (photons) from the sun to generate electricity through the photovoltaic effect.

Proposed Solution:
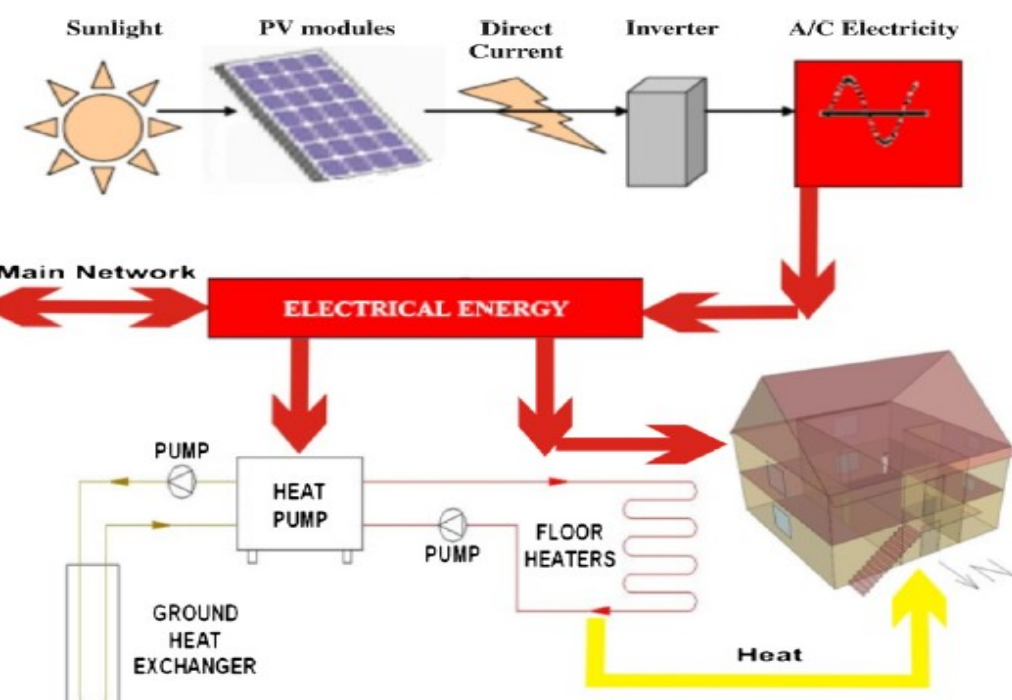

The above shown figure 3.1 shows that solar panels have been setup along with the residential building which serves as a source of power generation apart from the power which comes from the utility grid. The diagram clearly shows the the house draws power from both the sources. When the power coming from the utility grid id insufficient then the excess power needed comes from the solar panel. If the power drawn from the panel is excess then the excess power can be given back to the grid for future use. This is the concept of positive-net-energy building shown by the block diagram.

II. Methodology:

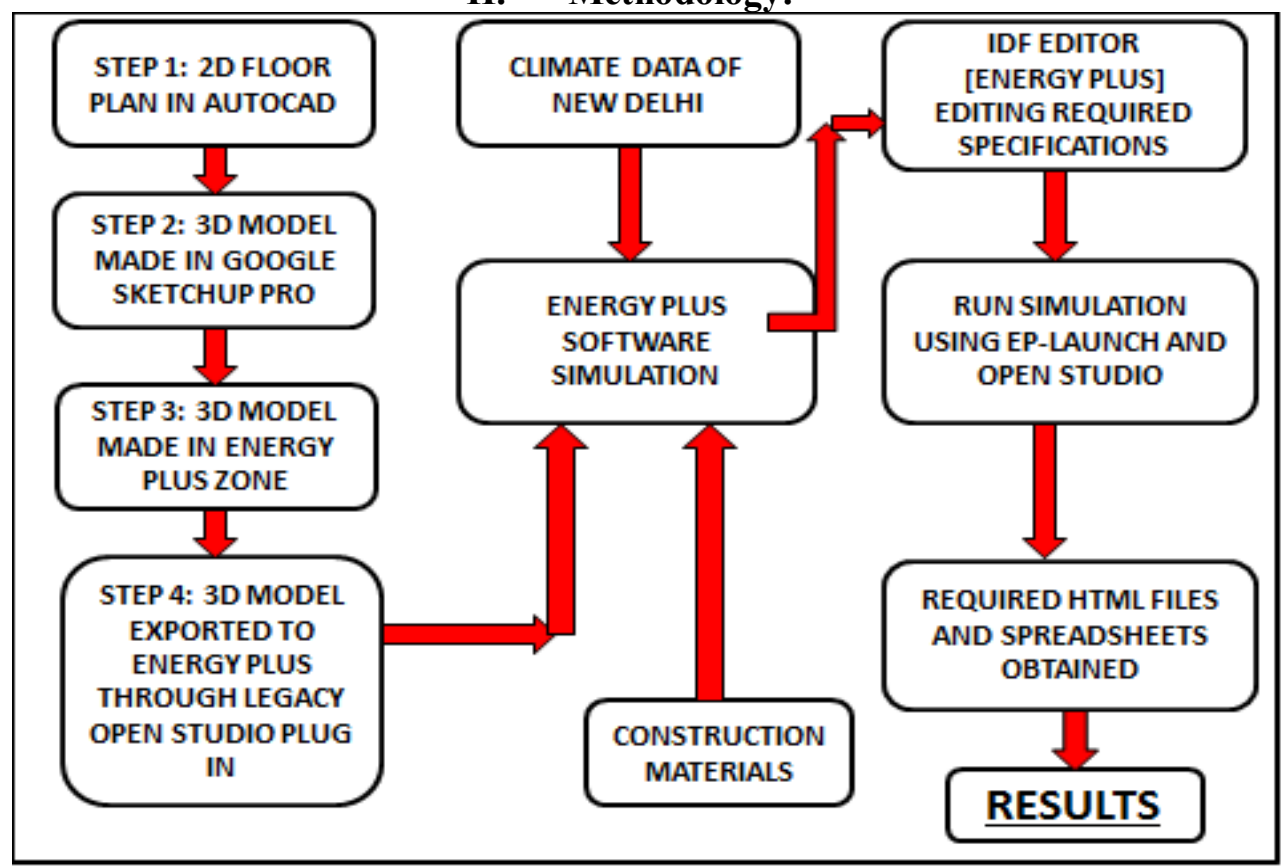




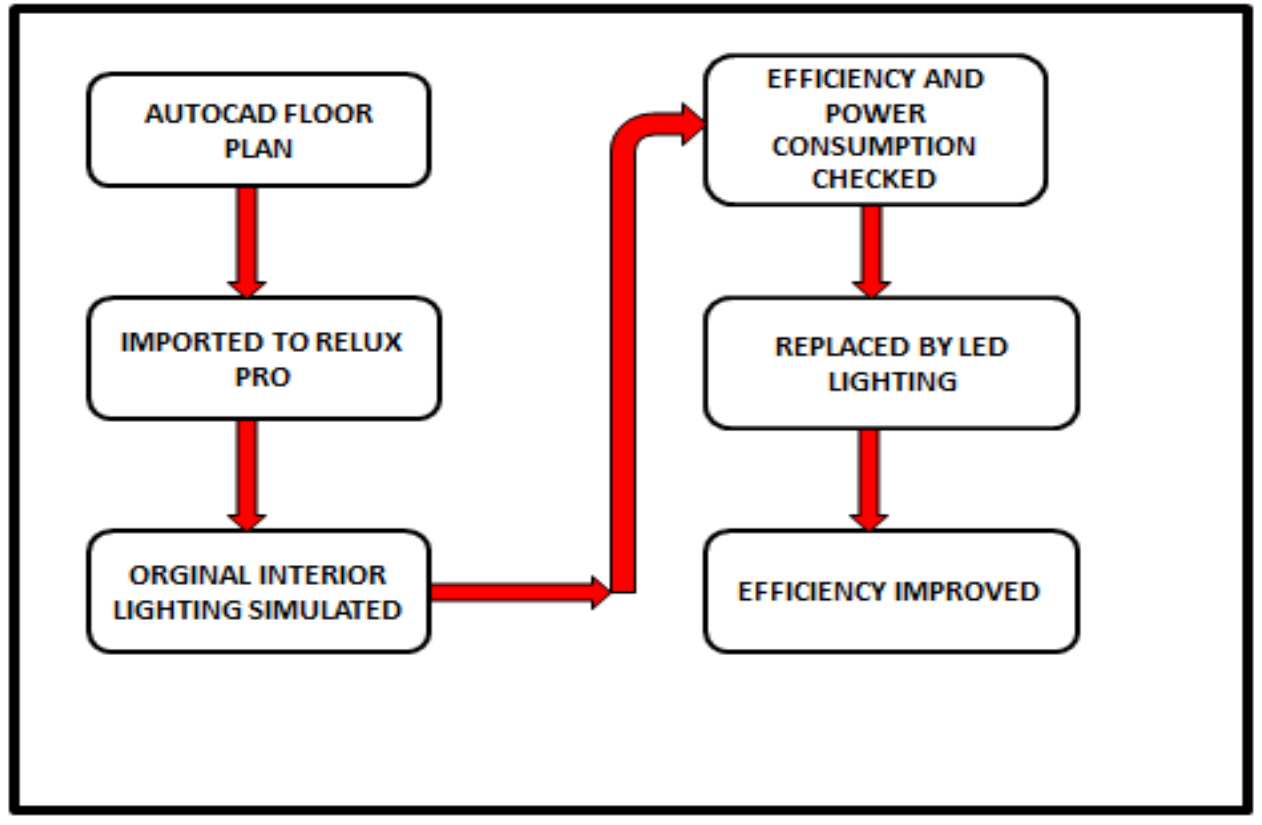

\section{Implementation:}

Using this software we obtain the 2 dimensional floor plan of the residential building.

Once this step is completed we scale the floor plan and export it to Google Sketch-up for the three dimensional modelling and simulation.

Therefore the floor planning is one of the most basic steps to have a proper idea about the area to be simulated.

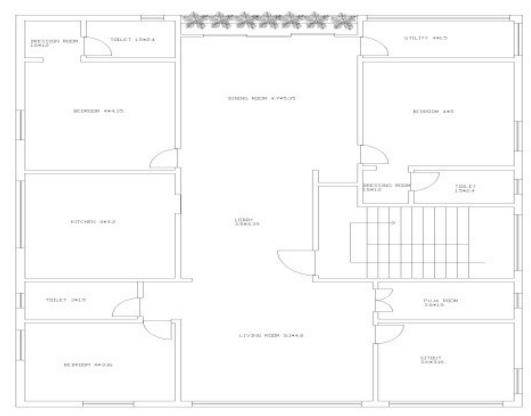

GOOGLE SKETCH-UP WITH OPEN STUDIO PLUG IN 


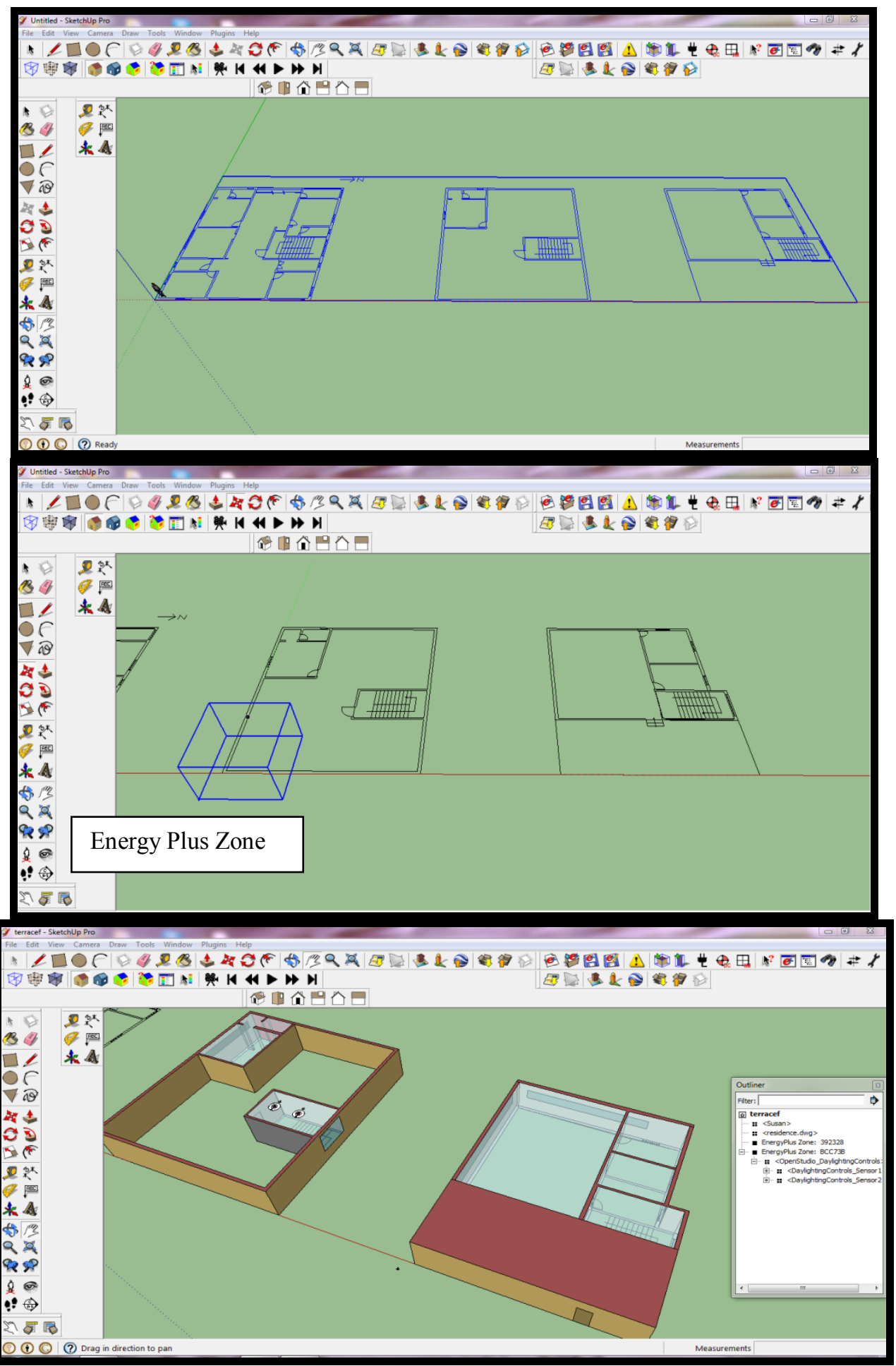




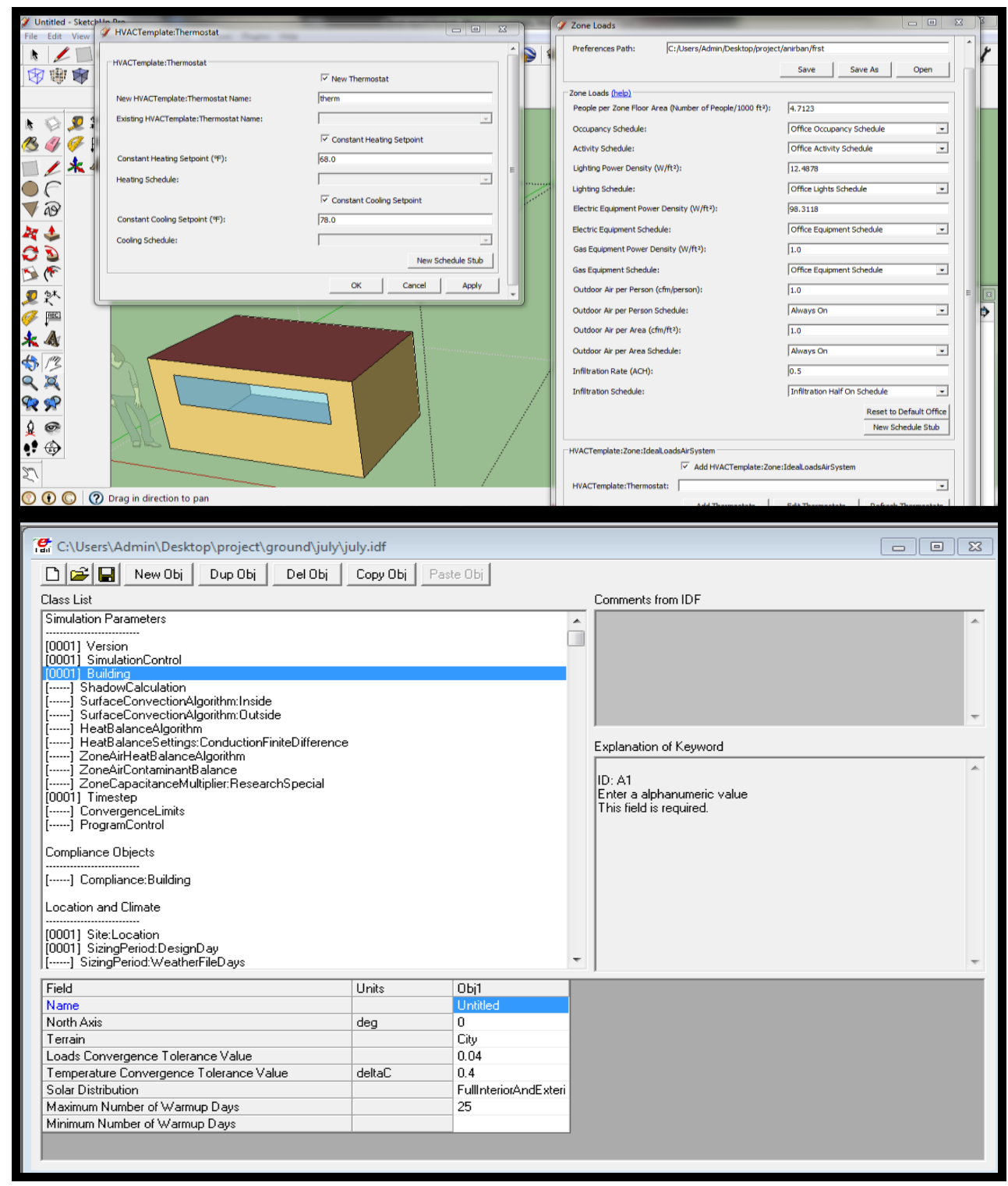

III. Simulation

After making the required changes we save the file in the editor.

Then we return to Sketch-up and open the Energy Plus input file from Sketch-up.

After this, through the plug in menu, we go to "RUN SIMULATION" option.

The following figures will display the procedure after this.

There is another way of simulating the files. We can also simulate through EP-Launch. Both the methods will be shown in the following figures. 
Method 1: Through Plug-In

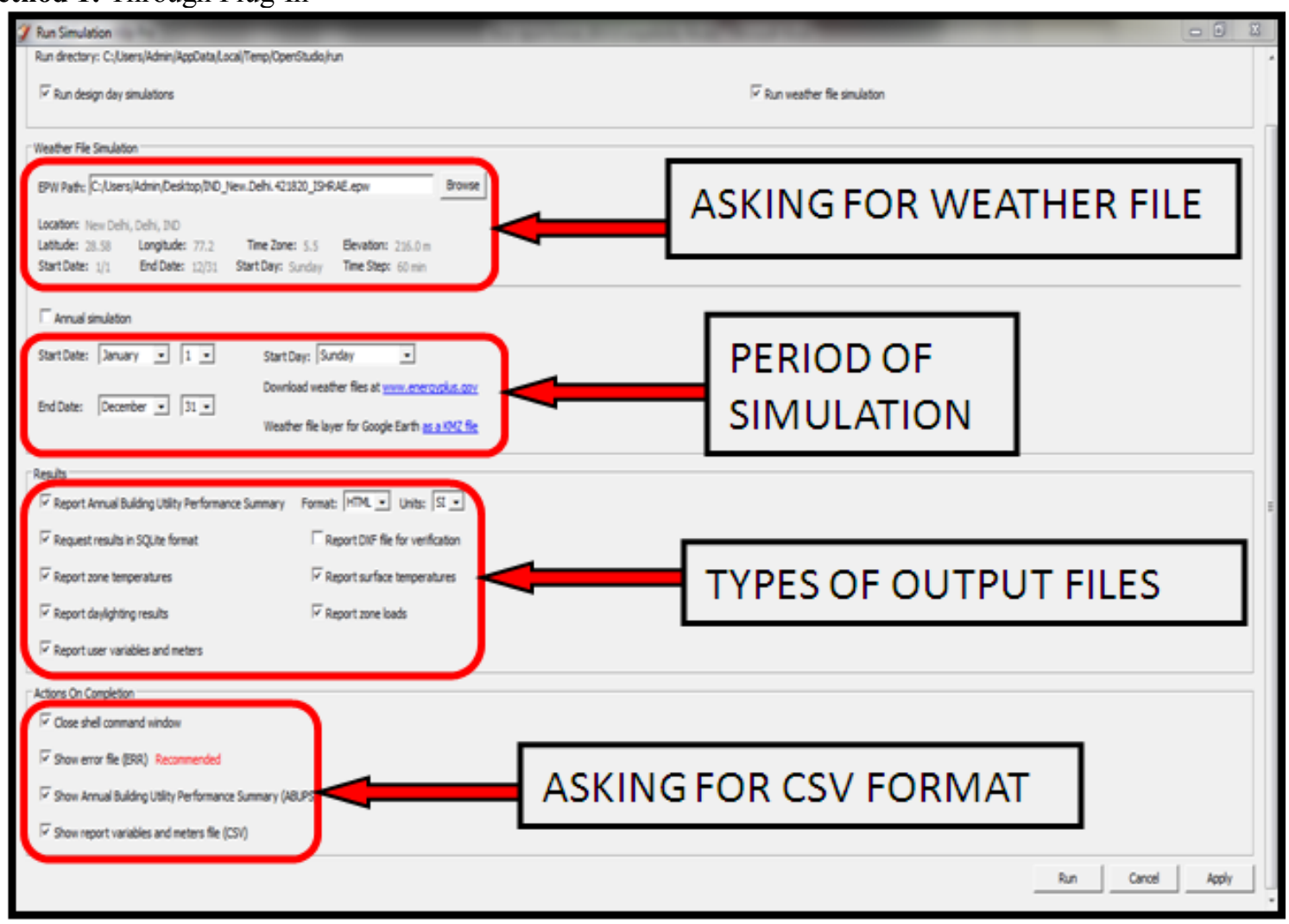

Method 2: Using Ep-LAUNCH

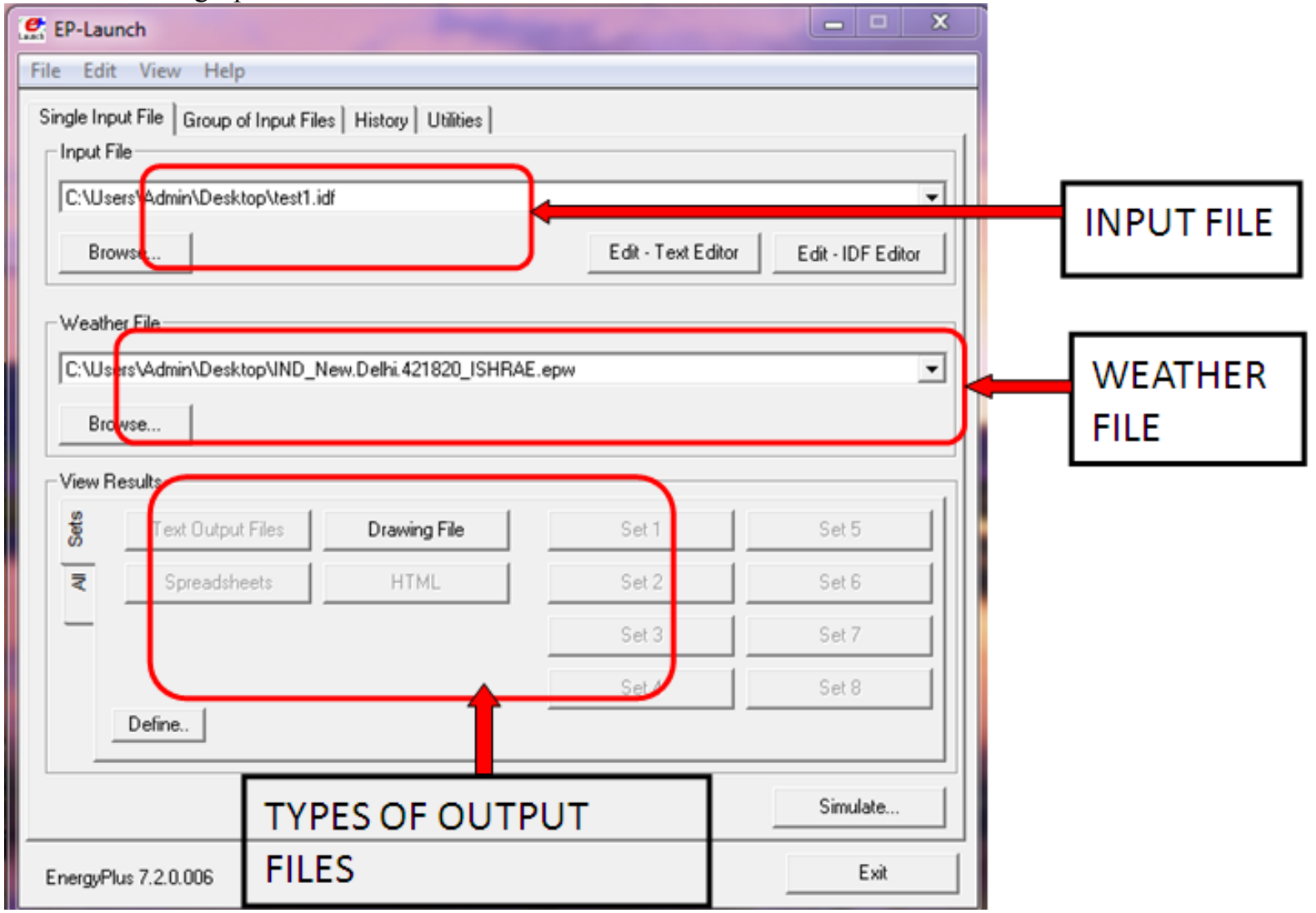




\section{RELUX}

RELUX is the lighting software which gives the outputs of interior lighting. The following steps will show the procedure to simulate a room in relux.

Step 1:

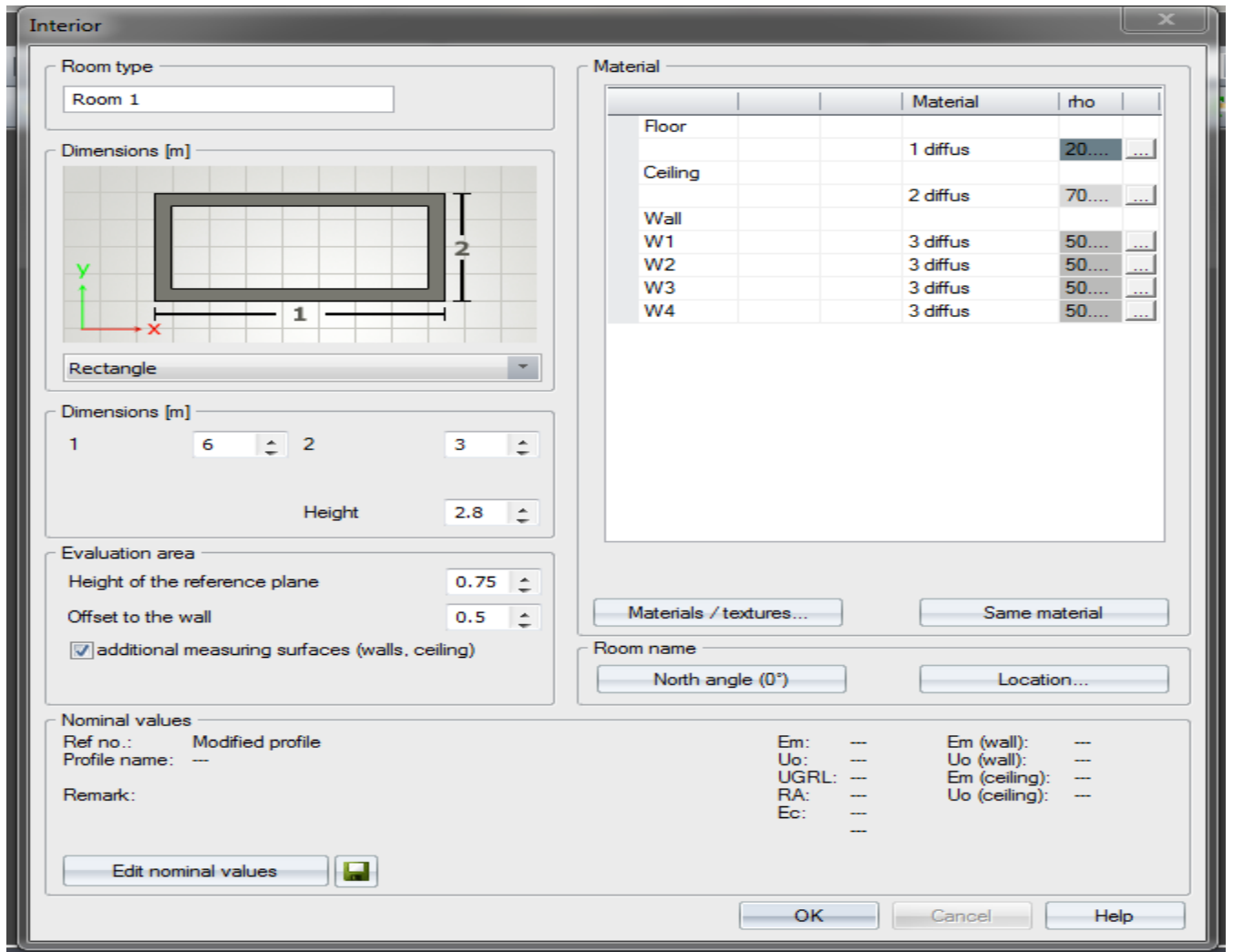

Figure 3.30: dimension to be set

The above figure shows how to set the dimensions of the room. Along with this, a tab for location is also visible [marked in red], using this we can set the geographical latitude and longitude for this.

After this we set the properties of each surface like material, colour, etc. relux offers a wide range of materials, colours and textures to be selected from. Apart from this the doors and windows need to be placed at the right places according to the floor plan.

After this the 3D objects need to be placed at the right places. Relux offers a wide range of 3D objects. The position of the $3 \mathrm{D}$ objects have to be set by positioning the coordinates. Selection of luminaires and positioning them followed by simulation. Three ways of simulation can be done: artificial, daylight or artificial+daylight.

After this we simulate the model to get the desired outputs.

\section{Panel Design}

The used PV panels are made from polycrystalline silicon.

Table 3.1: Panel Characteristics

\begin{tabular}{|l|l|}
\hline PANEL CHARACTERISTICS & VALUE \\
\hline SHORT CIRCUIT CURRENT & $4.7 \mathrm{~A}$ \\
\hline CURRENT AT MAXIMUM POWER & $4.2 \mathrm{~A}$ \\
\hline VOLTAGE AT MAXIMUM POWER & $26.8 \mathrm{~V}$ \\
\hline TEMPERATURE COEFFICIENT OF OPEN CIRCUIT VOLTAGE & $-0.115 \mathrm{~V} / \mathrm{K}$ \\
\hline $\begin{array}{l}\text { TEMPERATURE COEFFICIENT OF SHORT CIRCUIT } \\
\text { CURRENT }\end{array}$ & $0.002 \mathrm{~A} / \mathrm{K}$ \\
\hline OPEN CIRCUIT VOLTAGE & $32.8 \mathrm{~V}$ \\
\hline NUMBER OF CELLS IN SERIES & 54 \\
\hline PANEL AREA & 1.037 met sq. \\
\hline PANEL HEAT CAPACITY & $50000 \mathrm{~J} / \mathrm{K}$ met sq. \\
\hline PANEL HEAT LOSS COEFFICIENT & $30 \mathrm{~W} / \mathrm{K}$ met sq. \\
\hline
\end{tabular}

RESPECTIVE METHODS OF PANEL DESIGN FOR PNEB, ZNEB AND NNEB:

Total energy consumption=ETY. This power is divided into 3 sections 
ETH, Y: space heating purpose

ETL, Y: lighting purpose

ETO, Y: other devices

This energy is produced by the pv system.

$\mathrm{PV}$ system $=\mathrm{PV}$ array + Inverter

OUTPUT ENERGY TERMS:

- $\quad$ ET, j-electrical energy consumed by the building

- $\quad$ EG, j-electrical energy purchased for the building from the grid

- $\quad$ EPV1,j-electrical energy generated by the panel of size $1.037 \mathrm{~m}^{\wedge} 2$

- $\quad$ EPV, j-electrical energy generated by PV array

- $\quad$ EPVB, j-electrical energy of the PV used by the building

- $\quad$ EPVG, j-electrical energy of PV sent back to the grid

$\mathrm{E}$ total $=\mathrm{EPVB}, \mathrm{y}+\mathrm{EG}, \mathrm{y}$

Generation of energy by PV \& consumption of energy by Pv don't occur simultaneously if greater energy is produced it is sent back to the grid else excess power is taken from the grid.

\section{ELECTRICAL ENERGY GENERATED ANNUALLY BY THE PV:}

$\mathrm{EPV}, \mathrm{y}=\mathrm{EPVB}, \mathrm{y}+\mathrm{EPVG}, \mathrm{y}$ (it has 2 sub-divisions)

EPVG, y = EPVGG, y + EPVGS, y

EPVGG, y: Actually compensates for the amount of electrical energy taken from the grid when PV is not available.

EPVGS, y: True surplus of the PV electrical energy

THUS IF,

$\mathrm{EPVG}<\mathrm{EG}(\mathrm{EPVG}=0) \rightarrow \mathrm{NNEB}$

EPVG $>$ EG $($ EPVGS $>0) \rightarrow$ PNEB

OPERATION OF THE BUILDING:

Yearly expense to purchase energy from grid (when house has PV)

$\mathrm{SG} \mathrm{y}=\mathrm{Cg} * \mathrm{EG}, \mathrm{y}$.

Maintenance cost (fixed) $=1 \%$ of I 0 i.e., $\mathrm{R} 0=0.01 \mathrm{I} 0$

When house doesn't have PV, then yearly expense

Sty $=\mathrm{Cg} * \mathrm{ET}, \mathrm{y}$.

Revenue generated by selling PV energy to grid

$\mathrm{RPVG}$ y $=\mathrm{Cpv} * \mathrm{EPVG}, \mathrm{y}$

$=$ RPVGG y + RPVGS y

Where, Cpv: price at which pv energy is sent to the grid

RPVGG y-compensation cost

RPVGS y-net revenue collected due to PV array

So yearly income is:

$\mathrm{D}=(\mathrm{STy}-\mathrm{Sgy})+\mathrm{RPVGy}-\mathrm{R} 0$

INVESTMENT IN PHOTOVOLTAIC:

$\mathrm{I} 0=\{(1+$ Cmount $) /(\mathrm{I}$ array $+\mathrm{I}$ inverter $)\}$

I array: investment for the PV array

I inverter: cost for the inverter

$\mathrm{C}$ mount: count of mounting

I array: $\quad \mathrm{F}$ array*S array*C array

F array: total area

S array: $\quad$ rated power $/ \mathrm{m}^{\wedge} 2\left(113 \mathrm{wp} / \mathrm{m}^{\wedge} 2\right)$

$\mathrm{C}$ array: price of array per unit (4.44euro/wp)

I inverter: $1.1 * \mathrm{~F}$ array*S array*C inverter

$\mathrm{C}$ inverter: price of inverter per unit $(0.512 \mathrm{euro} / \mathrm{wp})$

Cost for mounting is $10 \%$ of total investment

So total I0 is given by:

$\mathrm{I} 0=1.1 *(\mathrm{~F}$ array*S array* $\mathrm{C}$ array $+1.1 * \mathrm{~F}$ array* $\mathrm{S}$ array* $\mathrm{C}$ inverter $)$ 
INVESTMENT RETURN:

The investment return of application of the PV system

$\mathrm{PB}=(\mathrm{I} 0 / \mathrm{D})$ Where Io stands for the investment cost to supply and install the PV System and D stands for the yearly income when operating the PV System.

\section{Results:}
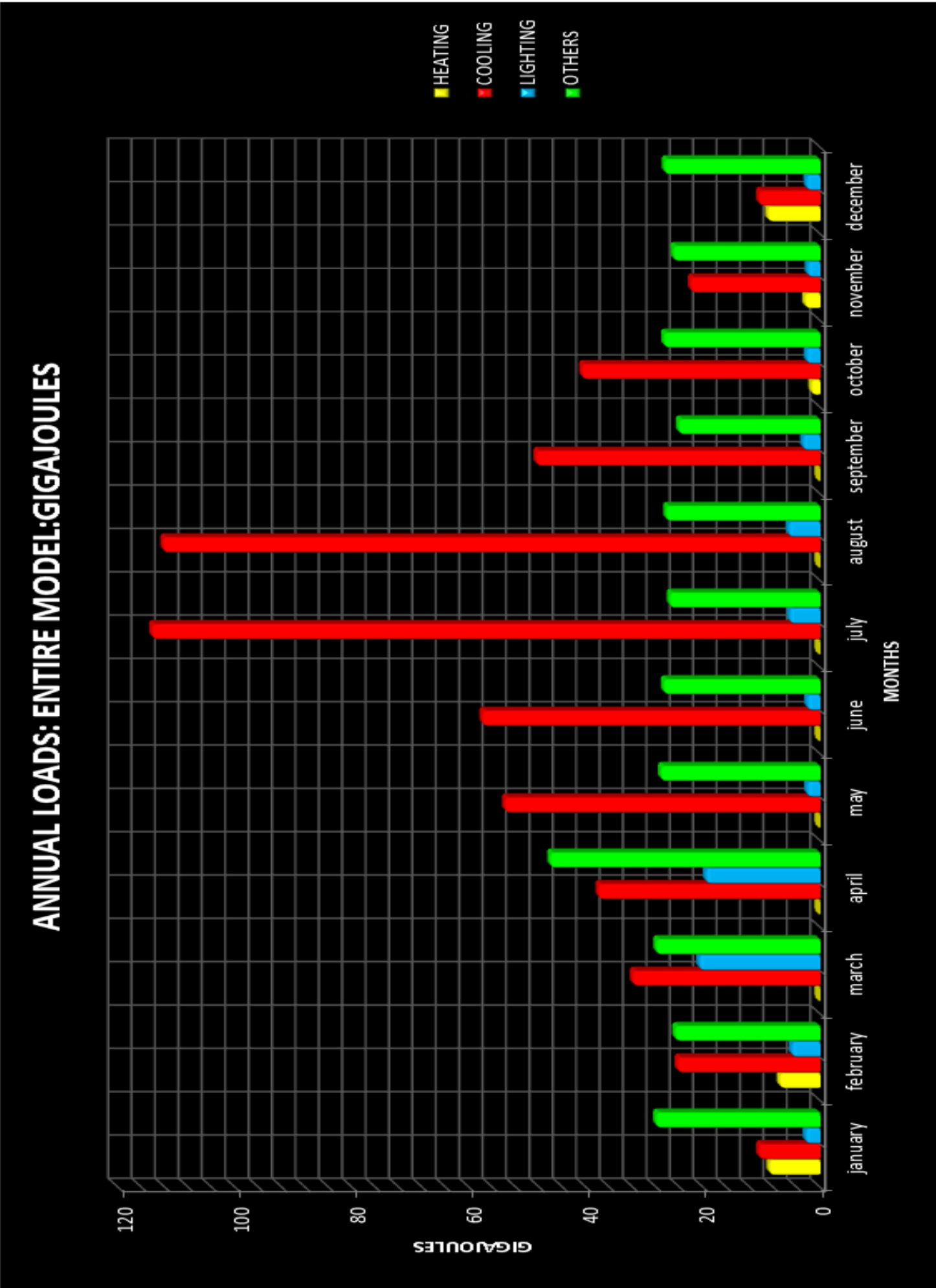

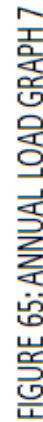




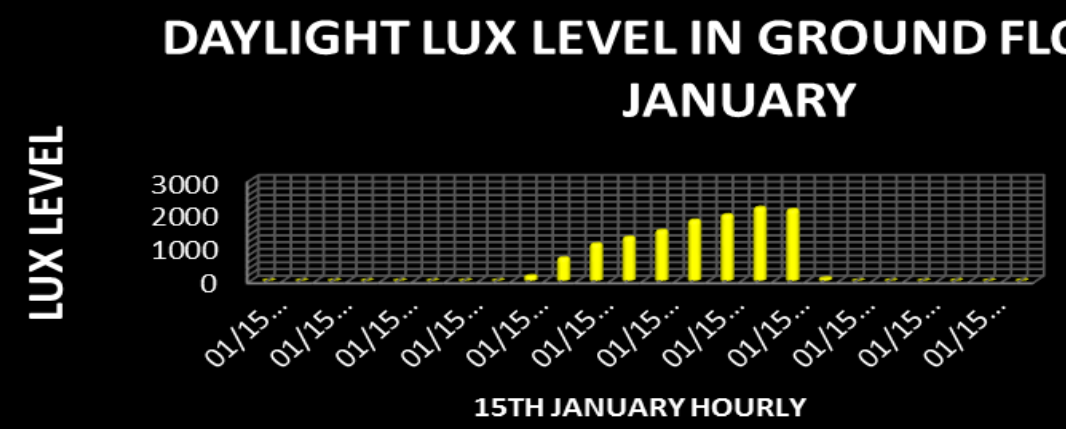

\section{DAYLIGHT LUX LEVEL IN GROUND FLOOR HALL:}

\section{JUNE}

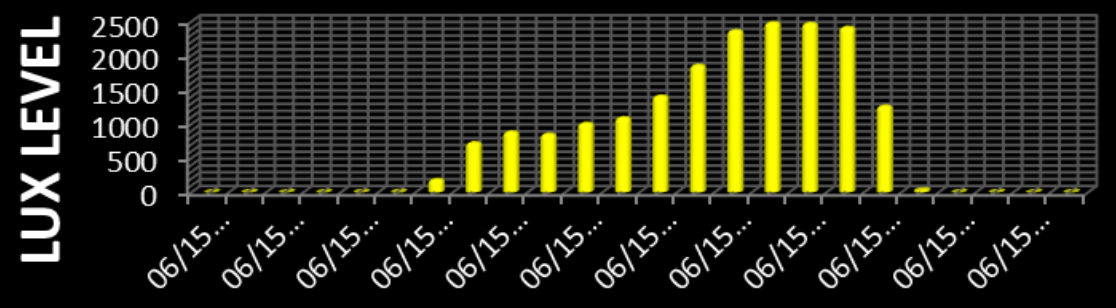

E DAYLIGHT LUX

\section{TH JANUARY HOURLY}

EXPLANATION: the above given graphs clearly show that the daylight lux levels is much higher in June than January as per New Delhi's climatic conditions.

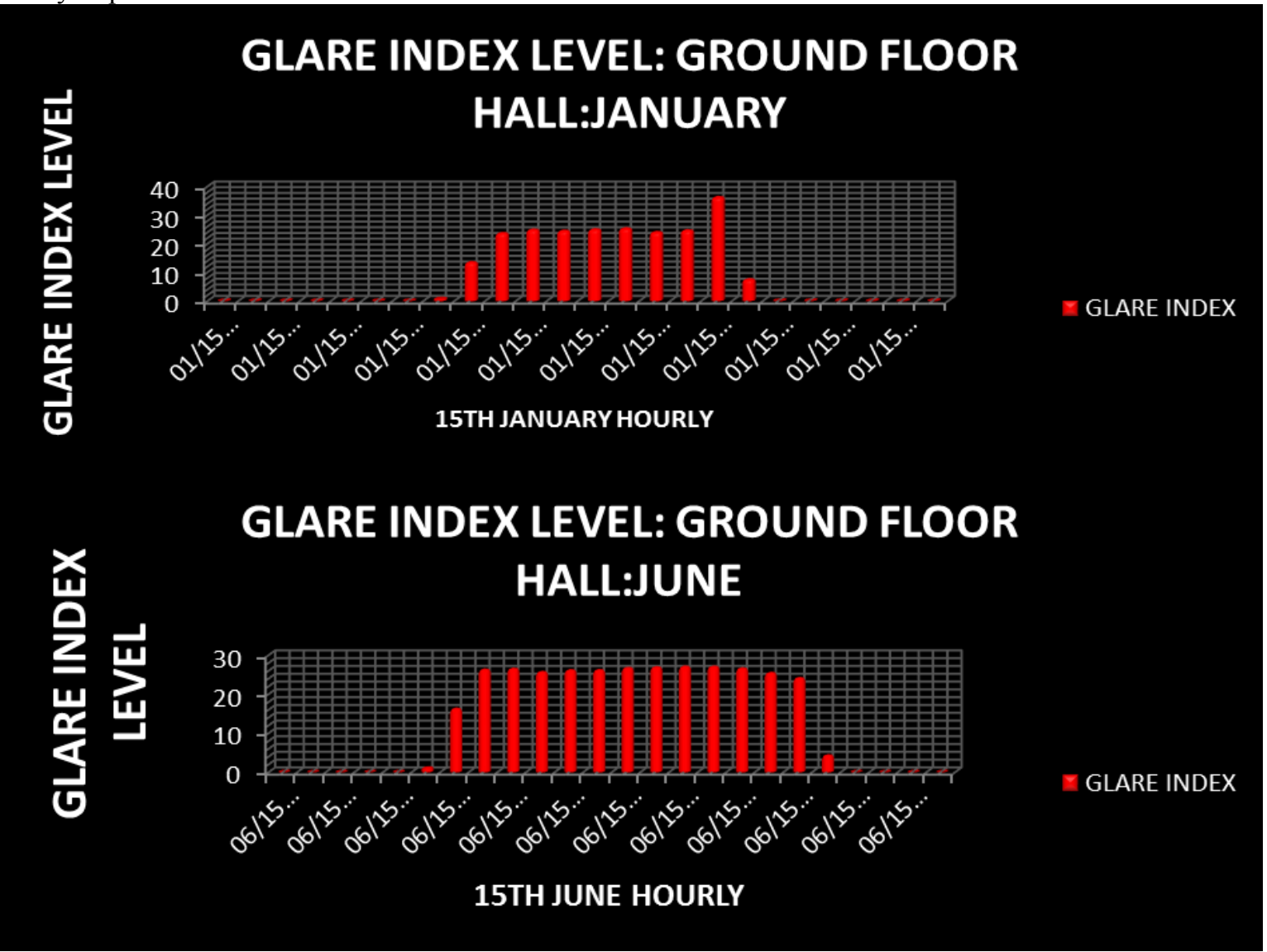

EXPLANATION: the above graphs clearly show that the glare index levels in January and June are more or less equal with little changes. They are almost the same with more uniformity in June. 

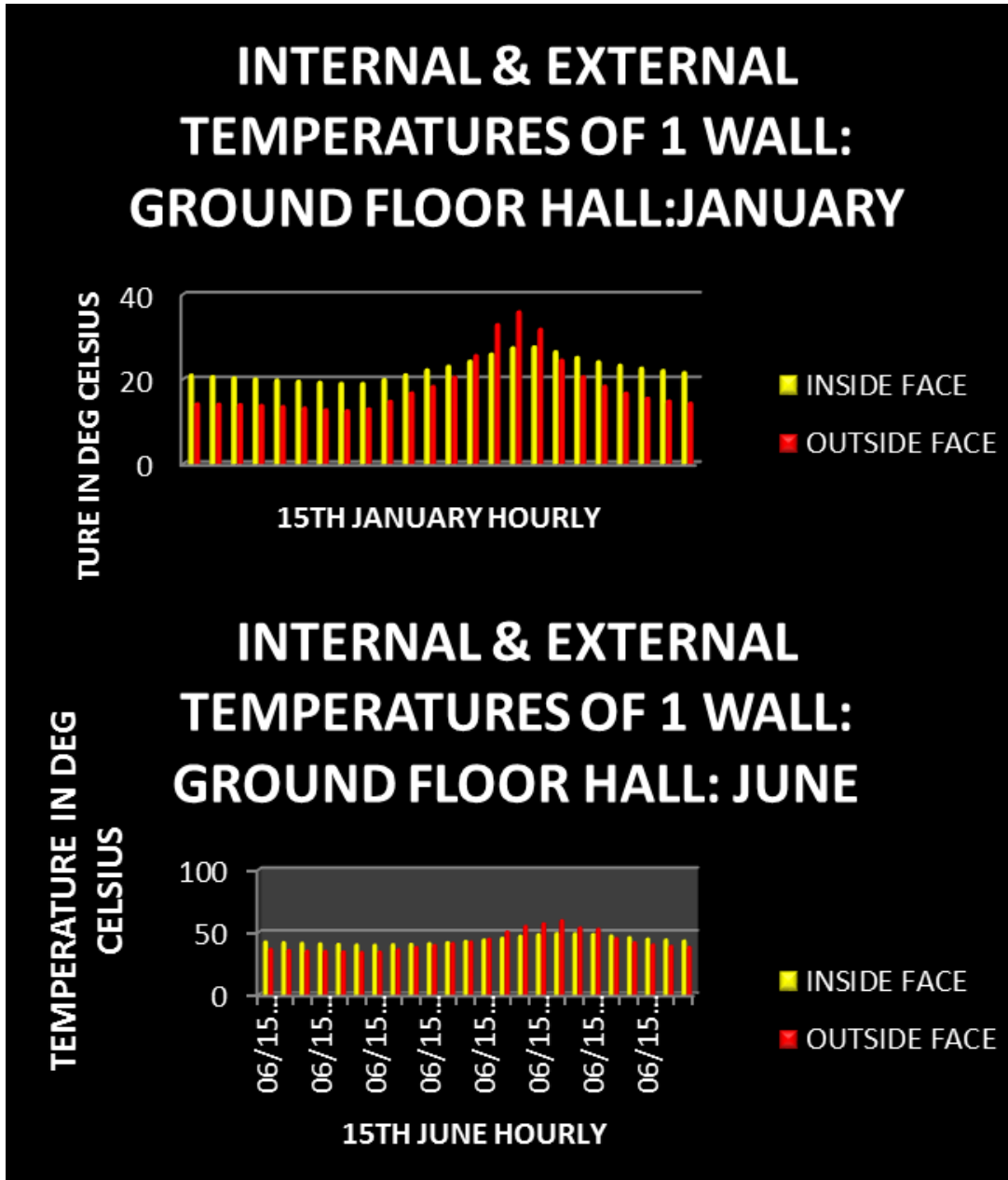

EXPLANATION: the 2 graphs given above give the surface temperatures inside and outside of 1 wall of the terrace bedroom. The first graph shows in January and the second one in June. It is clearly visible that in January the inside temperature is hotter than outside whereas in June the outside temperature is clearly higher than the inside face.

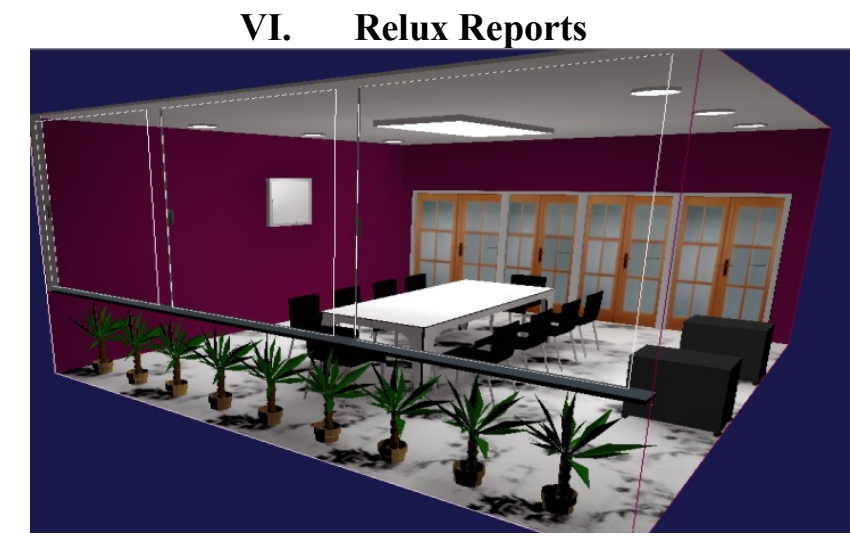

Relux 3dimensional Model:

Bedroom First Floor

Area: $4.7 * 5.35 \mathrm{M}^{2}$

Artificial Light Simulation

Conventional 
Power consumed: 163.8 watts

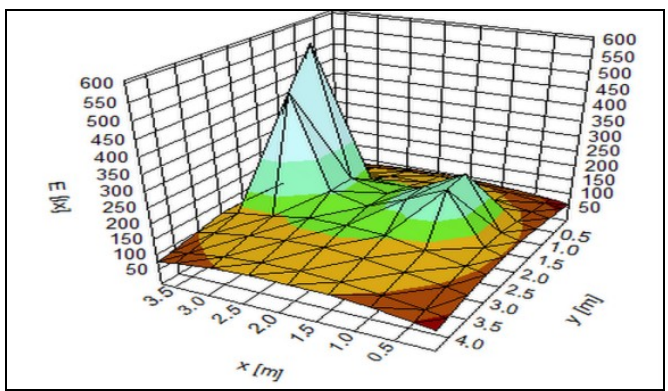

Max lux: 193

Min lux: 177

led

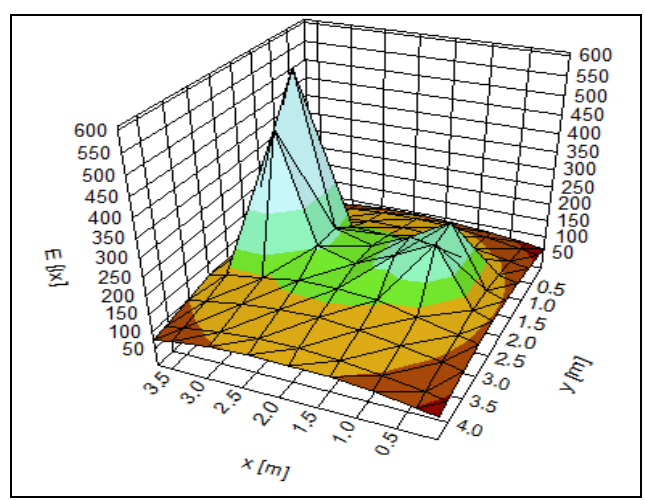

Power consumed: 152 watts

Max lux: 364

Min lux: 212

\section{POWER CONSUMPTION LEVELS}

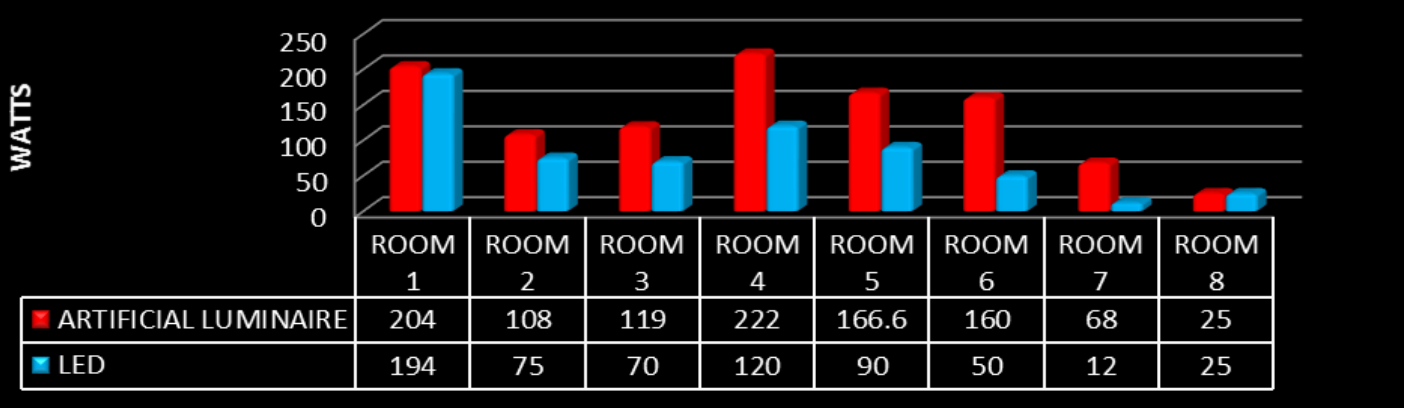

EXPLANATION: The graph and the above models and calculation clearly show that when the artificial luminaires are replaced by LED lamps, the power consumption is much lesser whereas the lux levels are comparitively higher.

Thus to improve energy efficiency, it is very useful and is highly possible to implement it. PANEL DESIGN:

Loads:

Space heating $=1380+[3 * 1871]=6990 \mathrm{~W}$

Lighting load $=2640 \mathrm{~W}$

Other purpose $=11800 \mathrm{~W}$

NNEB: Area of panel $=1.15$ met. Sq No. of panels required $=2$

ZNEB: Area of panel $\quad=3.5257$ met.sq No. of panels required $=4$ 
PNEB: Area of panel $\quad=12$ met.sq

No. of panels required $=12$

ANNUAL ELECTRICITY CONCUMPTION:

COST OF UNITS:

FIRST $200 \mathrm{UNITS}=3.70 \mathrm{INR}$

NEXT 200 UNITS $=4.80 \mathrm{INR}$

AFTER 400 UNITS $=6.40 \mathrm{INR}$

Expenses for consumed electricity when the house does not have PV array:

$\mathrm{S}_{\mathrm{TY}}=483427.3 \mathrm{INR} /$ year

Expenses to purchase the electricity from the utility grid

$\mathrm{S}_{\mathrm{GY}}=322377.6 \mathrm{INR} /$ year

Surplus energy produced $=$ half of space cooling $=3500 \mathrm{KW}=350$ units $/$ day

$350 * 30=10500$ units/month

$200 \rightarrow 3$ Rs. $\rightarrow 600 \mathrm{INR}$

$200 \rightarrow$ Rs. $\rightarrow 800 \mathrm{INR}$

$10100 \rightarrow 6$ Rs. $\rightarrow 60600 \mathrm{INR}$

Monthly revenue $\rightarrow 62000$ INR

YEARLY REVENUE : 744000 INR

INVESTMENT TO SUPPLY AND INSTALL THE PV SYSTEM: $\mathrm{I}_{0}$

$1.1 *\left\{\left(\mathrm{~F}_{\mathrm{ARR}} * \mathrm{~S}_{\mathrm{ARR}} * \mathrm{C}_{\mathrm{ARR}}\right)+\left(1.1 * \mathrm{~F}_{\mathrm{ARR}} * \mathrm{~S}_{\mathrm{ARR}} * \mathrm{C}_{\mathrm{INV}}\right)\right\}$

$=3286686.08 \mathrm{INR}$

REVENUE GENERATED BY SELLING THE PV power: $\mathrm{R}_{\text {PVGY }}$

$322377.6+744000$

$=1066377.6 \mathrm{INR}$

YEARLY INCOME:

$\mathrm{D}=\left[\mathrm{S}_{\mathrm{TY}}-\mathrm{S}_{\mathrm{GY}}\right]+\mathrm{R}_{\mathrm{PVGY}}-\mathrm{R}_{0} ; \mathrm{R}_{0} \rightarrow 0.01 \mathrm{I}_{0}$

$=161049.7+1066377.6-32866.86=1194560.44 \mathrm{INR}$

PAYBACK PERIOD:

$\mathrm{PB}=\mathrm{I}_{0} / \mathrm{D}=2.75$ YEARS

$=2$ YEARS 9 MONTHS. 